TEME, г. XLII, бр. 4, октобар - децембар 2018, стр. 1389-1404

Оригинални научни рад

DOI: $10.22190 /$ TEME1804389P

Примљено: 3. 11. 2017.

UDK 327

Ревидирана верзија: 16. 6. 2018.

Одобрено за штампу: 11. 7. 2018.

\title{
GEOPOLITICS OF CONTAINMENT IN THE POST COLD WAR WORLD
}

\author{
Igor Pejić ${ }^{a}$ \\ University of Belgrade, Faculty of Political Science, Belgrade, Serbia \\ amon.sum@gmail.com
}

\begin{abstract}
The main goal of this paper is to explain the need for geopolitics and how it influenced the decision making of various statesmen throughout political history. Since ancient times, geopolitical conditions have determined the courses and strategies of various civilizations driving them into conflict or allowing them to prosper. In the 19th century geopolitics became a necessary knowledge for statesmen, politicians and leaders who wished to engage into a turbulent arena of world politics. For them the geopolitics provided awareness and information about other world players, about their assets and liabilities, strengths and weaknesses. Following the rules of geopolitics grand strategies have been designed. The grand strategy of containment marked an entire epoch in modern human history. Employed by the US, containment was aimed against the Soviet Union in order to curb its expansion and to sustain the balance of power. Although successful, after its initial objective took a new shape of statehood, containment as a strategy had a rough time adjusting to the new world order. First section of the article will be dedicated to the development of geopolitics and how it influenced the states and their foreign policy decision making. In the second part of the article there will be an attempt to explain how containment worked as a grand strategy during the Cold War, its objectives, methods of applications and most importantly how does containment work in our contemporary world and is it viable as a strategy for achieving foreign policy goals?
\end{abstract}

Key words: Cold War, Containment, Foreign Policy, Geopolitics, Grand Strategy.

\section{ГЕОПОЛИТИКА ОБУЗДАВАЫА У ПОСТХЛАДНОРАТОВСКОЈ ЕРИ}

\begin{abstract}
Апстракт
Циљ овог рада је анализа геополитике која је током политичке историје усмеравала одлуке бројних државника. Од давнина геополитика је утицала и одређивала стратегију и смер којим би се цивилизације кретале, често водећи их у рат или им је доносила просперитет. Током 19. века геополитика је постала
\end{abstract}

${ }^{\mathrm{a}} \mathrm{Ph}$.D. Student 
непоходно знање за све државнике, политичаре и владаре који су желели активно да суделују у турбулентој светској политици. За њих је геополитика пружала неопходне информације о другим играчима, о њиховим предностима и манама. Пратећи правила геополитике, изродиле су се различите стратегије. Тако је Велика стратегија обуздавања обележила једну читаву епоху у модерној историји. Настала као америчко оружје против совјетског режима, стратегија обуздавања имала је за циљ да заузда совјетски експанзионизам и да одржи баланс моћи. Иако успешна, стратегија обуздавања суочила се са многим проблемима у новом светском поретку када је њен почетни циљ нестао са светске сцене. Први део чланка посвећен је развоју геополитике и њеном утицају на спољну политику држава. Други део рада усредсређен је на стратегију обуздавања током Хладног рата, на њене циљеве и методе, као и на тренутну ситуацију у свету, односно на питање да ли оваква стратегија данас може бити применљива.

Кључне речи: Хладни рат, обуздавање, спољна политика, геополитика, Велика стратегија.

\section{INTRODUCTION}

Geography has been a decisive factor which vastly influenced the development of various civilizations, propelling them to greatness or leaving them in the dust. Superpowers governed by these principals have shaped their policies and grand strategies in order to defeat their adversaries on the global stage. During the Cold War, the US devised the strategy of containment hoping it will allow them to deter the Soviet threat and secure its global dominance. The strategy built upon the foundations of classical geopolitics proved successful. However, at the dawn of the $21^{\text {st }}$ century the newly created world order didn't support the classical premises of geopolitics. The post-modern concept has exhibited new factors, requirements and players on the geopolitical field that were radically different from those of the classical age. Containment strategy as a remnant of the classical geopolitics needed to adjust and keep the pace with the current world affairs. This article will try to explain the dichotomy between classical and postmodern concepts of geopolitics and how it influenced the grand strategy of containment, how the strategy worked in the Cold War era and can it be employed in the present age.

Given the introduction, the main question of the research article will be focused on the relevance of the containment strategy in today's world. However, since the strategy of containment began as an idea of classical geopolitics which later entered into a post Cold War concept it is important to explain and acknowledge the contrast between these two schools of thought. Explaining the differences between the classical and postmodern concept of geopolitics and how it reflected on containment strategy, both quantitative and qualitative research approaches will be employed. The quantitative method is used primarily in the sense of gathering literature and research articles which are focused on the geopolitics of containment 
and how their terminology and conception are explaining this idea. The qualitative approach is focused on textual and comparative analysis of these papers, especially focusing on the works of Mackinder, Spykman, Kennan, G. O. Tuathail and their ideas about geopolitics. The goal of the qualitative approach is to break down the structure of these papers and see how the strategy of containment functioned in the Cold War and how it functions today.

\section{GEOPOLITICS - THE THEORETICAL APPROACH}

Politicians, leaders, statesmen, countries and even whole societies may change, however the geography of the area will most likely remain the same and continue to influence the following generations. Nicholas Spykman in his book "The Geography of the Peace" simply and plainly observed: "Geography is the most fundamental factor in foreign policy because it is the most permanent." (Owens, 2015, p. 463) Author Colin S. Grey (1996, p. 248) further defines geography as a factor which determines physical location and character of a state and its populace. Geography separates the national territory of one state from all others, it defines culture of that nation and finally it shapes the country's political and historical choices. Different geographical settings may provide distinctive opportunities or impose difficult constraints which are reflected on the state's foreign policy and strategy. In other words geography defines the players and the stakes which they try to hold while always determining the field and terms in which they measure their power and security relative to others (Grey, 1996, p. 249). This is a vision of a political geography and geopolitics which is the discipline's subdivision. Geopolitics essentially represents geographic relevance in political and strategic context for the pursuit of international power. Geopolitics, as such are mostly related to the branch of strategic geography which is focused on control or access to certain areas that have a profound impact on security, development and overall prosperity of nations (Owens, 2015, p. 463). The idea of geopolitics, or geography and politics is very old and dates back to the ancient Greece whose philosophers first saw the correlations between Earth's geography and the state's politics and how it reflects on the human society. The modern term of geopolitics which we are familiar with comes from the Swedish academic Rudolf Kjellen formulated at the dawn of the $20^{\text {th }}$ century (Garfinkle, 2003, p. 263).

Geopolitics had and has many protégés who interpret it and explore it in their own design or according to their country's interests. One of the most famous geographers who propelled geopolitics into the mainstream science and state politics is Sir Halford Mackinder. Addressing the Royal Society of Geographers in London Mackinder introduced his "pivot theory" also known as the Heartland, after which he quickly managed to inject his ideas into the 
strategic thinking of statesmen but most importantly into the minds of English leaders (Fettweis, 2015, p. 234). Although Mackinder reaffirms the importance of geography and geopolitics as an "aid to statecraft" the originality of his ideas can be debatable. Namely most of his ideas came as responses to the geopolitical approach of Alfred T. Mahan and his geopolitics of the sea (The Influence of Sea Power upon History) in which Mahan argues that controlling the world oceans is the key to global domination. Mackinder on the other hand argued that the region of Eurasia or World Island, with its Heartland as the most prosperous area richest in resources, can provide enough wealth for a country to ascend to global supremacy. The geopolitics of land power which Mackinder was advocating for was quickly welcomed by the British government at that time. This was no surprise since the British were engaged in Central Asia with the Russian Tsardom in the $19^{\text {th }}$ century, therefore Mackinder's theories of Heartland and the "Pivot area of History" resonated heavily within the Kingdom. Although his Heartland theory didn't produce a world hegemon, Mackinder's echo can be heard in the works of various writers. In his book Democratic Ideals and Reality, Mackinder refers to Eurasia as the main geopolitical objective: Who rules East Europe commands the Heartland: Who rules the Heartland commands the WorldIsland: Who rules the World-Island commands the World. (Mackinder, 1942, p. 106). This concept had a profound influence on the ideas of Haushofer, Spykman, and the shatter-belt design and most importantly on the Cold War grand strategies.

Karl Haushofer a German intellectual redefined Mackinder's ideas of Heartland into the idea of lebensraum which served as one of the guiding points for the Reich's political ideology. Also known as the Nazi Machiavelli, Haushofer heavily influenced American international rhetoric during the Cold War with his understanding of geopolitics which "was not a means of understanding the balance of power, but of overthrowing it." (Garfinkle, 2003, p. 264) Haushofer described geopolitics as a child of geography, an important subject which all state leaders need to be familiarized with while at the same time emphasizing that studying geopolitics or Geopolitik must be done from the present or future view rather than from the past. His commitment to the study of geopolitics as a tool for predicting the future was also reflected on his stance towards politics. He considered politics a living science able to shape the future perspective of nations rather than retrospective, often resenting the German politicians of that time whose stance towards politics was similar to dead history (Haushofer, 1942, p. 34). On the other side of the Atlantic Nicholas Spykman reinvigorated Mackinder's idea in the American way with his "Rimland" theory (Fettweis, 2015, p. 234-237). Some thinkers argue that the Spykman's theory completely disproves the Heartland since it is contained by Rimland and thus deprived of the ocean access, hence the land power cannot be projected any further, making it to a certain extent 
meaningless. Although at the first glance this may seem true, nevertheless one theory doesn't necessarily make the other obsolete. Both of them are not contradictory in nature, but rather complementary - building upon each other. Furthermore the same theories made a huge impact on George Kennan's containment idea during the Cold War and even at the present day and age both Heartland and Rimland represent crucial geopolitical realms in which great powers are playing their game of chess.

Geopolitics is often referred to as the game of "risk". Though no one can disregard the similarities, the science behind the discipline is much deeper. Geography, the starting point for geopolitics, is often characterized as a descriptive science of world exploration. However with the ending of the era of exploration and entering a post-Columbian epoch, the world became a closed system and the struggle for power and supremacy among the states entered a zero-sum game. Within the new world Mackinder argued that geography needed a new rationale. For Mackinder the "old" geography was overburdened by large quantities of statistical and descriptive information, a generic science secluded from humanity and its interests. Mackinder tried to give geography a new "shell" through political prism, he urged for the necessity of combining "natural geography with political geography". Namely instead of perceiving geography as a solely descriptive science the discipline could be employed as a state tool in order to help the state leaders achieve their international goals (Mayhew, 2000, p. 774-787). Here again we can see the strong national sentiment in Mackinder's rhetoric and its patriotic dedication to the English crown. Unlike geography, geopolitics most of the time cannot employ a scientific method nor express its arguments in a manner which would be appropriate for a scientific testing. One of the usual critiques which are aimed at geopolitics is that it fails to explain coherently the behavior of states, although the scholars of geopolitics often turn to prescription and even in some cases to prediction rather than creating a consistent design of political behavior (Fettweis, 2015, p. 237238). The critique aimed at geopolitics for not providing an explanation for state behavior was somewhat supplemented by geostrategy.

Geostrategy as a strand of classical geopolitical thought is interested primarily in discovering certain patterns of state development and behavior in a broader geographical context. Alfred T. Mahan, an American naval officer, was well known for successfully exercising this discipline. Mahan successfully predicted the struggle between Russian land and British sea power in the region settled between Turkey and Manchuria, the same region which more or less encompassed Mackinder's Heartland. For Mahan this was a "debatable middle strip" a zone of turmoil in which great powers would clash their swords. Also Mahan's predictions were serving as a foundation block for the shelterbelt concept or a "zone of turmoil" which Richard Hartshorne described as "an area of contention caught between two powers or geostrategic realms" (Owens, 2015, p. 8) . It is very important to 
note that Mahan's ideas were implemented later in Spykman's Rimland theory and also served as a blueprint for the containment concept during the Cold War.

Nicholas J. Spykman, a protégé of classical geopolitical thought, argued that war is inevitable and it is an instrument of national policy. Furthermore, he describes the state's territory as a base from which it operates during war while also serving as a strategic position during the "temporary" peace. The country's territory is crucial for Spykman because it is the most permanent factor, therefore country's politics must be adjusted to it accordingly. He also formulated the objectives which states peruse and tools needed for successful statecraft. The objectives could be: geographic, racial, ethnic, economic, social, political or ideological; supplemented with the appropriate tools and methods of statecraft such as: cooperation, accommodation and opposition followed by persuasion, barter, coercion and subversion (Furniss, 1952, p. 386-388). Although Spykman provides a thorough explanation on how geopolitics influences the country's position in international environment, it still fails to predict or explain the state's behavior. Though geography and strategy are converged in geopolitics, the discipline solely cannot provide explanation for future behavior of states. Nevertheless geopolitics is dynamic, it reflects international realities of interaction of geography, economy and technological development and how they correlate with the state and its position in the international relations (Owens, 2015, p. 477-478).

Besides classical school of geopolitics, which made a decisive influence on the Cold War strategies of containment, there are also other schools that are important to mention. The development of geopolitics was essentially influenced by the age in which their authors were residing. Therefore we have imperialist geopolitics, normative geopolitics, Cold War geopolitics and critical geopolitics; however some schools have been developed in accordance to their object of study or their authors' interests. Even the classical school of geopolitical thought is divided among "land power theory", "sea power theory", "national organism theory" and "edge district theory" (Zhiding and Dadao, 2016, p. 1773). In his paper "Power and Paradox: Asian Geopolitics and Sino-American Relations in the 21st Century" M. Evans (2011, p. 88-98) explains that because of China's rapid development three particular schools have been interested in this East Asian phenomena. The primacist, exceptionalist and pragmatic school of thought. All three of them are trying to explain the Chinese global ascendance and the fulcrum of East Asia through realistic, culturally deterministic and security perspectives. Even though all the mentioned authors and their respective works are important in order to understand the world and its harsh realism of power struggle, one school in particular is vital for understanding the modern, multi-polar, post-Cold War world order. 
Critical school of geopolitics goes further to explain the geopolitical arrangement of the world and international relations after the Cold War. Developed by the researchers such as Gearóid Ó Tuathail, John Agnew and Simon Dalby, critical geopolitics is trying to merge modern political discourses, statements and practices rather than simply providing a descriptive framework between geography and politics. Three factors in particular have influenced the development of this fresh discipline in geopolitics, that include: alterations in the pattern of geopolitics after the Cold War; a more divided research field; and the desire of many researchers who felt that it was necessary to correlate new political practices with the new ideas of geopolitics after the Cold War (Zhiding and Dadao, 2016, p. 1773). One of the creators of critical geopolitics, Gearóid Ó. Tuathail defines it as an approach which tries to problematize assumptions and ontological commitments of classical geopolitics. Critical geopolitics tries to challenge the state-centric view of world politics by deconstructing hegemonic political discourses while questioning the relationships of power in the geopolitical practices of dominant states. The same author, G.Ó. Tuathail, further argues that informationalization, globalization and risk society as postmodern geopolitical conditions are challenging the modern geopolitical assumptions. ${ }^{1}$ The technology which is now available to us provides unparallel interconnectedness across the globe. Boundaries between local, national and global are slowly fading while the whole world society is functioning on multiple levels but in the same real-time perspective. State power and capitalist territoriality were main distinctions of modern geopolitical condition, while the postmodern geopolitical condition has a growing disjunction between these two terms. Each of the states had its own economic backyard governed by state regulations, while in postmodern geopolitical condition the evolving process of globalization is organizing state's economy on a different level where structures of financial power are beyond the reach for even the most powerful in the world politics (Tuathail, 2000, p. 166-170). The postmodern geopolitics is marked by the momentum of globalization which is driven by increasing speed, instability and collaboration between players on the global stage. The main difference between the modern and postmodern is reflected in division and integration also known as "fragmegration" ${ }^{2}$. The modern geopolitical concept during the Cold War was a "wall", a division between

\footnotetext{
${ }^{1}$ Modern geopolitical conditions are based on state-centric assumptions such as: states have a complete sovereignty over their territory, domestic and foreign affairs are two different realms, boundaries of a state are clearly defined and are perceived through its society.

${ }^{2}$ The concept includes two distinctive processes of globalization which are embodied in integration and fragmentation which unfold simultaneously in the world society. The idea was conceptualized by James Rosenau.
} 
the capitalist West and the socialist East; while the postmodern concept is perceived through the "World Wide Web" and its integrative speed. Threats to the nation state have also changed. In the Cold War era the enemy was clear and well-known as well as his arsenal. In the postmodern era the enemies are blurred and hidden, the anxiety that was once induced from the knowledge of your enemies' powers of annihilation is being replaced by anxiety towards the unknown, fear of the rapid change and the enemies which cannot be seen, touched nor felt (Luke, 2003, p. 228-229). The threats are becoming increasingly non-territorial. Although the spatial dimension is still present, risks and dangers for the post-modern society cannot be contained in the traditional sense. "The new threat paradigm" dictates different rules of the game revealed mainly through the global risk society and deterritorialized threats. Therefore the whole integrative character of globalization is interlaced with systematic contradictions, political vulnerabilities manifested in crisis of governance prompted by the next generation of threats (Tuathail, 2000, p. 170-174).

Despite the tide of post-modern discourse essential concepts of geopolitics are still alive and active. Concepts of power, territory and boundaries still continue to define the international sphere. State power is still present and it is exercised by the state's authority, although it is not "stored" on the domestic level exclusively rather it fluctuates as a medium between the states. The concept of state territory and sovereignty established in the $17^{\text {th }}$ century with the Treaty of Westphalia still dictates political movements of modern day sovereigns. Territoriality as an institutionalized principle influenced the state building process giving effective mechanism for social integration and administration development. Furthermore, all states are concerned with their territory and potential resources that may be discovered or exploited. Boundaries, yet another remnant of classical age, are lines which give state's territory a materialized frame of sovereignty. Boundaries are ways in which we define ourselves and separate "us" from "them". They don't need to be strictly territorial, boundaries can be social or cultural, and nevertheless they still separate one entity from the other giving it a unique place of residence. Although today due to modern technology and globalization boundaries are not so definitive and rigid they still influence the development of a nation and its political choices. Boundaries today are both present on territorial and non-territorial plain (virtual space) influencing the dynamics of states' power (Allen, 2003, p. 95-109). Despite the end of the Cold War and Fukuyama's pompous work "The End of History and the Last Man" world politics are still being defined by the same aspects of geopolitics only modified in order to suit the needs of the present age. Therefore observing the concept of critical geopolitics and postmodern condition shouldn't be treated as a rupture from classical geopolitics but rather a continuation of the practice harmonized with the age in which we live in. The world has 
changed after the fall of the Berlin Wall, nevertheless strategies employed by Great Powers back then resonate in today's world in a different form but with the same purpose: hindering the power of other players while trying to assert yours as superior in the global political arena.

\section{GRAND STRATEGY OF CONTAINMENT - PAST, PRESENT AND FUTURE IMPLICATIONS}

The Cold War which began shortly after the Axis threat was gone, represents a period of time marked by confronted ideologies, looming threat of thermonuclear destruction, pursuance for balance of power in bipolar world and grand strategies of two hegemons. The uneasy collation gathered around the idea of stopping the Third Reich easily dispersed when the threat was gone. The world superpowers had a rough time adjusting to the new world order. Issues over certain shatter zones such as the Balkans, Middle East, Korea and Eastern Europe were only the initial budge that later evolved into a full blown conflict without the actual war.

The Cold War was embodied in a couple of different dimensions. Ideology, although not a primary reason for the Cold War, quickly became the separating alignment between the opposing sides. Another dimension was the "arms race". Developing technologies and massive spending in the military sector resulted in an arms race which could have easily turned into a very hot thermonuclear war. The "third world" dimension represented as the periphery allowed both blocks to test their capabilities without the threat of directly engaging, but also with a potential reward of spreading their spheres of influences. The last dimension was of internal nature especially present in Moscow's politics, the need for an external enemy in order to justify your own domestic reign. This somewhat existential dimension $^{3}$ was essential for the USSR when the government became excessively repressive (Gaddis, 1981, p. 74-77). Across this multidimensional character of the Cold War, that also contributed to its longevity, grand strategies were tailored in order to maintain the balance of power.

Before discussing containment as a grand strategy which shaped the foreign policy of the United States for almost five decades we need to understand the term of grand strategy, what it means and how it employs various ideas and strategies into a coherent state plan. Grand strategy incorporates ultimate security objectives and the means with which to achieve them that go far beyond military policies while also extending to economic, diplomatic, social and political instruments of the state (Biddle, 2007, p. 461). Grand Strategy is "intellectual architecture that gives form

\footnotetext{
${ }^{3}$ This existential matter and the need for the outer enemy is somewhat evident and distinguishable in today's NATO rhetoric towards Russia.
} 
and structure to foreign policy". ${ }^{4}$ Grand strategies usually mirror the needs and aspirations of the state in the current age. Although at the first glance the term grand strategy may seem as a strictly rational objective based on the principles of realpolitik, the design usually has many architects ultimately giving form to their views, characters and beliefs. Statesmen act on the basis of certain beliefs which sometimes are not articulated clearly, furthermore the legacy of their predecessors more often than not leaves a mark on their ideas (Zakaria, 1990, p. 374). Grand strategy of containment, although representing a firm objective of containing the Soviet expansion, wasn't created solely by George Kennan. While G. Kennan is deemed as the most important figure for this strategy others like Hans J. Morgenthau, Walter Lippmann, Harry S. Truman and many others modified this strategy in accordance with the current world events. Therefore, when referring to a grand strategy despite its name it is not a monolith structure that defines the rules of the game, rather it is a flexible term which is molded and adjusted by events, circumstances, statesmen and the age in which it is employed. Grand strategies in general can be divided among defensive and offensive strategies. US grand strategy during the Cold War was defensive in general while Germany's grand strategy in 1939 was offensive. The nature of the strategy is ultimately determined by its goals. Containment in its core was a defensive grand strategy focused on containing the Soviet expansion and power on the Eurasian landmass. Other notable US grand strategies during the Cold War that could have served as an alternative for containment include: world order idealists, neo-isolationism, disengagement, global containment and rollback (Walt, 1989, p. 6-9). Despite occasional misgivings the strategy of containment worked relatively well and enjoyed a substantial popular support.

Containment may be described as a preservationist policy, a policy where two powers are intertwined over global supremacy where one power deems another one inherently evil and expansionistic; therefore it is crucial to contain it and limit its influence and aspirations. American containment, as envisioned by its creator G. Kennan, was directed towards the Soviet expansion primarily with the implementation of the Marshall's plan. The initial idea of economic containment represented a more moderate approach, however after the Korean war and an overall aggressive Communist rhetoric gave containment a more militaristic dimension (Welch, 1973, p. 230-231). Moreover containment was also expressed in symmetrical or asymmetrical form. Symmetrical containment implies that the adversary will be countered at the same place, time and in the same manner as enemy thrusts, ${ }^{5}$ while the asymmetrical approach chooses

\footnotetext{
${ }^{4}$ Cited according to E.E.Spalding, (2017). The Enduring Significance of the Truman Doctrine. Foreign Policy Research Institute: Elsevire Ltd. p. 13.

${ }^{5}$ Korean and Vietnam wars are the best examples of symmetrical containment.
} 
favorable places, times and manners in which it will respond. While the first is "cost-maximizing" and "risk-minimizing" the other one is "costminimizing" and "risk-maximizing". Both of these variations have been employed during the Cold War. Choosing between them usually reflected the swings in the defense budget and the threat capacity of a certain event or a Soviet political move (Zakaria, 1990, p. 383-384). A more geopolitical view of the containment strategy also suggests its spatial dimension. Territorial expansion was still an important factor during the Cold War, controlling vast resource areas gives greater military potential and the ability to effectively project power. Soviet Union as a Eurasian superpower was naturally expanding into the Rimlands of the World Island threatening the non-communist states of the region. Governed by Spykman's ideas and fearing the consequences of the domino theory the US officials embraced a more classical geopolitical approach treating the communist expansion as a direct threat to the security of the United States (Dalby, 1990, p. 179-180). The spatial dimension in the containment strategy was also reflected through the Korean War and later in the Vietnam as well as countering the Soviet invasion in Afghanistan. In the finite world territory is subjected to the zero-sum calculations, if someone takes a piece there is less for others. However in today's multi-polar world presumptions of classical geopolitics, although present, are being pushed aside by postmodern concepts of geopolitics in designing the contemporary policies of containment.

Containment in the post Cold War world has remained an important strategy of the United States, however since the Soviet threat took a new shape containment as a policy has been redirected toward other political entities which are considered a threat to the newly established world order. The end of the Cold War also signified the end of the bipolar world, therefore the strategies which were designed for the purpose of that age have lost their significance and function to a certain extent. Containment, however, as one of the primary aspects of US foreign policy in dealing with the Soviet Union, managed to re-establish itself in a different form in the new world against newly emerged threats. In the post Cold War world instead of containing a global superpower the United States directed its containment strategy against the so called "rogue states". ${ }^{6}$ Many of these rogue states have belonged to the "third world" or in the periphery during the Cold War. Although unimportant back then, during the eighties, countries such as Libya, Syria, Iraq, Iran, N. Korea and others have become a security issue for the US policy makers. During the nineties the new concept of containment was developed and was aimed at these regimes in

\footnotetext{
${ }^{6}$ Rogue states or international pariahs can be described as states with repressive regimes whose domestic conduct led them to be isolated from the rest of the world. Often these states are suspected to help terrorist organizations, possess weapons of mass destruction and generally threaten the world peace.
} 
order to restrain them and limit their potential to destabilize the international system. Dual containment was introduced directly after the Gulf War against Iraq and Iran, natural leaders in the region at that time, in order to prevent them from becoming the dominant powers in the Middle East (Hubbell, 1998, p. 9). However the new containment wasn't a standalone strategy as its predecessor. Usually when establishing containment in the multi-polar world order against pariahs states other strategic options are bound to follow. Appeasement, engagement, rollback and non-entanglement were strategic alternatives or supplements to containment, where rollback and engagement were most commonly used against rogue regimes. Rollback in its core implies a full-scale war against a rogue state in order to change the regime, other subtle forms of this strategy also include intense economic, diplomatic and military pressure in order to force the regime change in the country domestically. Engagement is a strategy of integration through contact, trusting the liberal assumptions of international relations and the good will of states (Dueck, 2006, p. 225-228). Although these strategies differ from each other, they still have a common attribute which puts them in the same basket. The "active" character of both rollback and engagement describe how strategies have changed in the post Cold War world in comparison to the "passive" character of the containment strategy. Although containment worked very well against the Soviets in isolating them from the rest of the world, isolating rogue states or similar international political entities is somewhat meaningless. Rogue states are pariahs because they are already isolated from the rest of the global society. Therefore containment may serve as a tool to restrain or limit the threat which these states may project, however containment cannot resolve the core issues in these countries.

Best examples of the "new" containment are evident in Iraq and Iran, however with questionable success. For ten years after the Gulf War Iraq had been subjected to the strategy of containment with the elements of indirect rollback. The goal was to deter Iraq from further aggression towards its neighbors and stopping Saddam in creating weapons of mass destruction. Various tactics which have been employed in order to contain Iraq (implementing no-fly zones, diplomatic and economic pressure, UN inspections etc.) have proven to be more or less insufficient. After the 9/11 incident the US administration decided to invade Iraq thus mitigating from containment to the rollback option embodied in a full blown invasion. Iran similarly to Iraq represents a threat in the Middle East for America and its regional allies, while the country's overall international rhetoric emphasizes its rogue character. However in the Iranian case the rollback option was deemed as too risky with a potential of spiraling into a regional conflict (Dueck, 2006, p. 230-238). Containment of Iran which is focused on stopping the proliferation of WMD is also directed towards limiting the Iranian political and religious influence in the region. American diplomatic 
efforts in engaging Iran on the multilateral level are still ongoing. Relatively successful, it seems that a diplomatic approach may work in stopping Iranian military nuclear program. However containing Teheran's political and religious influence in the region, especially after the events of the Arab Spring, may prove to be futile. Although labeled as a state which supports terrorism after the Islamic State's onslaught Iranian backed paramilitary groups were welcomed as saviors by the local population. Due to its past misgivings and failed policies in the Middle East the US approach towards efficiently containing Iran on all fronts won't be feasible. Unlike the Soviet era containment today US lacks credibility in certain parts of the world, therefore maintaining this strategy, whether in symmetrical or asymmetrical form, will prove to be costly with relatively limited results.

Besides these examples of the post-Cold War containment we shouldn't disregard the old antagonist. Despite the disintegration of the Warsaw pact the NATO alliance continued to thrive and expand. There are numerous explanations for this international military phenomena but one of the simplest was presented by Kissinger and Brzezinski - since Russia was unable to integrate to the new world order its failure to accept western democracy and implement the standards of liberal markets plunged the country into lawlessness and later towards oligarchy and authoritarianism. Henceforth, Russia is incapable to accept such values and by default will remain expansionistic. The best strategy in order to protect the western civilization was to enlarge NATO and deny Russia the possibility of gaining control in the post-Soviet space, especially in Ukraine therefore unquestionably establishing new grounds for the containment strategy (Lundestad, 2013, p. 214-215).

The first wave of NATO enlargement that started in the nineties only partly depicts the new American containment of the former Communist hegemon. The escalation of the Ukrainian crisis in 2014 is one of the best examples that the Cold War strategies are still largely present in the contemporary narrative of the global super powers. Although the "postmodern" containment differs in certain aspects from its predecessor such as the implementation of new military technology, new generation of warfare and broadness of global media involvement; it still reflects the basic drive of the United States politics towards Russia in Europe. The fears of the Russian bear that have been temporarily subsided due to the American euphoria of the unipolar momentum, have been yet again reignited by the Russian active foreign politics and fast accumulation of relative power. The post Cold War containment strategy evolved in accordance with Gearóid Ó Tuathail's vision of the post-modern geopolitical setting, that is to say the new strategy of containment is implementing and developing itself with all the merits of technology and globalization of our contemporary age. 


\section{CONCLUSION}

The strategy of containment helped the US prevail over the Soviet Union during the Cold War. Significance of this strategy and geopolitical engagement is unquestionable, it did not only help contain communism and the totalitarian rule of the Soviet regime but the strategy also made sure that the Cold War never reached its hot phase. As a remnant of classical geopolitical thought containment was built upon the ideas of Heartland and Rimland while also being strongly influenced by the domino theory. Controlling the Rimlands of Eurasia and denying the Soviets an easy access to warm water seas was crucial for the US strategy of containment to work. In the end the land power hegemon collapsed on itself proving that G. Kennan's grand idea was the correct path for the American Cold War politics. However in the post Cold War world the classical geopolitical premises are slowly becoming remnants of a bygone age, naturally the containment strategy has also been caught in this tide. Containment as a strategy which has foundations in classical geopolitics cannot be fully implemented in today's multi-polar world. Threats against which containment was visualized for, have radically changed and evolved. For classical geopolitics states were the only actors on the chess table. Today, as Gearóid Ó Tuathail argues in his post-modern geopolitical concept, non-state entities are immensely influencing the strategic choices of the states thus radically changing the classical geopolitical concept out of which containment was born. It's hard to imagine implementing containment in its original form against today's rising political powers such as Russia, China or India. Isolating these countries or trying to contain their influence by practicing the traditional forms of containment strategy in today's interconnected world is not entirely possible. More often we can come across "deterrence" or "power projection" as policies in which powers are trying to deter others from their spheres of influence or invade the same. Even against weaker political entities such as rogue states, containment couldn't provide the much expected results. From the perspective of smaller states such as Serbia the strategy of containment is hardly applicable. Though the strategy can be redesigned to fit the needs of smaller players and their regional agendas, on a bigger scale, more often than not, smaller countries are usually treated as particles of such strategy rather than its consumers. Nevertheless, as former Yugoslavia once played an important buffer position between the two power-blocks it is not unimaginable that Serbia with its policy of neutrality will play a bigger role in the coming multi-polar age.

Although containment in the post Cold War world cannot function in its primary form, it can still supplement other state strategic policies or perform in a different visage. In its primal form containment is nothing more than a traditional policy of power balance, using military or diplomatic tools to counter the potential aggressor. From this perspective containment will still have a role in today's multi-polar world order balancing the power among global players. 


\section{REFERENCES}

Allen, J. (2003). Power. In A Companion to Political Geography. (J.Agnew, K.Mitchell, G.Toal, eds.). Blackwell. Publishing. pp. 95-109.

Biddle, S. (2007). Strategy in War. PS: Political Science and Politics. Vol. 40. No. 3. pp. 461-466. https://doi.org/10.1017/S1049096507070941

Dalby, S. (1990). American security discourse: the persistence of geopolitics. Political Geography Quarterly. Vol. 9. No. 2, pp. 171-188. https://doi.org/ 10.1016/0260-9827(90)90017-5

Dueck, C. (2006). Strategies for Managing Rogue States. Foreign Policy Research Institute: Elsevire Ltd. pp. 223-241. https://doi.org/10.1016/j.orbis.2006.01.004

Evans, M. (2011). Power and Paradox: Asian Geopolitics and Sino-American Relations in the $21^{\text {st }}$ Century. Orbis. A Journal of World Affairs. Vol. 55. Issue 1. pp. 85-113. https://doi.org/10.1016/j.orbis.2010.10.004

Fettweis, C. J. (2015). On Heartlands and Chessboards: Classical Geopolitics, Then and Now. Orbis. A Journal of World Affairs. Vol. 59. Issue 2. pp. 233-248. https://doi.org/10.1016/j.orbis.2015.02.005

Furniss, E. S. Jr. (1952). The Contribution of Nicholas John Spykman to the Study of International Politics. World Politics. Vol. 4. No. 3. pp. 382-401. DOI: $10.2307 /$ 2009129

Gaddis, J. L. (1981). Containment: Its Past and Future. International Security. Vol. 5. No. 4. pp. 74-102. DOI: $10.2307 / 2538714$

Garfinkle, A. (2003). Geopolitics: Middle Eastern Notes and Anticipations., Orbis. A Journal of World Affairs. Vol. 47. Issue 2. pp. 263-276. https://doi.org/ 10.1016/S0030-4387(03)00004-8

Gray, C.S. (1996). A Debate on Geopolitics: The Continued Primacy of Geography. Orbis. A Journal of World Affairs Vol. 40. Issue 2. pp. 247-259.

Haushofer, K. (1942). "Why Geopolitik?” In The Geopolitics Reader (Gearóid Ó Tuathail, Simon Dalby, and Paul Routledge, eds). London and New York. 2003. pp. 33-36.

Hubbell, S. (1998). The Containment Myth: US Middle East Policy in Theory and Practice. Middle East Report. No. 208. US Foreign Policy in the Middle East: Critical Assessments. pp. 8-11 http://radioislam.org/historia/zionism/ containment_hubble.html, accessed 19.09.2017)

Luke, T.W. (2003). Postmodern Geopolitics. In A Companion to Political Geography. (J.Agnew, K.Mitchell, G.Toal, eds.). Blackwell. Publishing. pp. 219-236.

Lundestad, G. (2013). International Relations Since the End of the Cold War: New \& Old Dimensions. Oxford University Press.

Mackinder, H.J. (1942). Democratic Ideals and Reality - a study in politics of reconstruction. Washington DC, National Defense University Press.

Mayhew, R. (2000). Halford Mackinder's "new" political geography and the geographical tradition. Political Geography, Vol. 19. Issue 6. pp. 771-791. https://doi.org/10.1016/S0962-6298(00)00018-4

Owens, M.T. (2015). In Defense of Classical Geopolitics. Foreign Policy Research Institute. Elsevire Ltd. pp. 463-478. DOI: 10.1016/j.orbis.2015.08.006

Spalding, E.E. (2017). The Enduring Significance of the Truman Doctrine. Foreign Policy Research Institute: Elsevire Ltd. pp. 1-14. https://doi.org/10.1016/ j.orbis.2017.08.001

Tuathail, G.Ó. (2000). The Postmodern Geopolitical Condition: States, Statecraft, and Security at the Millennium, Annals of the Association of American Geographers, Vol. 90, No. 1, pp. 166-178. DOI: 10.1111/0004-5608.00192 
Walt, S.M. (1989). The Case for Finite Containment: Analyzing U.S. Grand Strategy. International Security. Vol. 14. No. 1. pp. 5-49. DOI: 10.2307/2538764

Welch, W. (1973). Containment: American and Soviet Versions. Studies in Comparative Communism. Vol. 6. Issue 3. pp. 215-240. https://doi.org/ 10.1016/0039-3592(73)90001-X

Zakaria, F. (1990). The Reagan Strategy of Containment. Political Science Quarterly. Vol. 105. No. 3. pp. 373-395. DOI: $10.2307 / 2150823$

Zhiding, H. and Dadao, L. (2016). Re-interpretation of the classical geopolitical theories in a critical geopolitical perspective. Journal of Geographical Sciences. Vol. 26. Issue 12. pp. 1769-1784. DOI: 10.1007/s11442-016-1357-1

\title{
ГЕОПОЛИТИКА ОБУЗДАВАҢА У ПОСТХЛАДНОРАТОВСКОЈ ЕРИ
}

\author{
Игор Пејић \\ Универзитет у Београду, Факултет политичких наука, Београд, Србија
}

\section{Резиме}

Геополитика или политичка географија дозвољава да разумемо предодређене природне факторе који утичу на стварање националне политике. Класична геополитика, са својим представницима попут Макиндера, Махана, Хаусхофера и Спајкмана, била је потпуно посвећена географији и природним факторима који су диктирали и одређивали спољнополитичке циљеве државе. Иако су долазили из различитих епоха, ови аутори су дубоко веровали у непроменљиви карактер географије, што се даље и одразило на њихово виђење државе и њене спољне политике. Њихове идеје касније су служиле као основа великим силама током Хладног рата како би осмислиле своје стратегије, одржавале или мењале равнотежу моћи. Обуздавање као једна од главних америчких стратегија тог периода заснована је на премисама класичне геополитичке мисли. Зачета од стране Џорџа Кенана, стратегија обуздавања усмеравала је америчку политику скоро пола века. Упркос свом стаменом изгледу, стратегија обуздавања често је варирала између симетричне и асиметричне опције, док је такође била модификована у складу са постојећим потребама америчке администрације и светских догађаја. На крају, стратегија обуздавања се исплатила, совјетска претња нестала је дозвољавајући Америци да успостави нови светски поредак након Хладног рата. Понесена пређашњим успехом, стратегија обуздавања наставила је свој пут у новом постхладноратовском свету. Ипак, у новом светском поретку, са новим претњама и изазовима, стратегија обуздавања наишла је на потешкоће. Као изданак класичне геополитичке мисли, стратегија обуздавања суочила се са постмодерним геополитичким концептом. Премисе на којима се засновала ова стратегија нису биле присутне у новом свету. Нове скривене претње, стална повезаност света и напредак технологије створили су окружење у којем стратегија обуздавања није исплатива. Упркос томе, стратегија обуздавања може да нађе своје место у новом мултиполарном свету, јер у суштини ова стратегија представља ништа више до политику баланса моћи у којој су сва средства дозвољена како би се непријатељ обуздао, а равнотежа моћи одржала. 